\title{
THE USE OF REAL-TIME PCR FOR EVALUATION OF ENDOMETRIAL MICROBIOTA
}

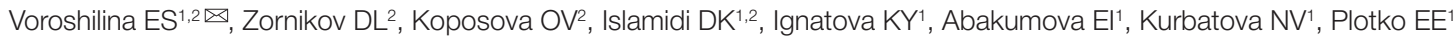

1 "Garmonia" Medical Center, Yekaterinburg, Russia

${ }^{2}$ Ural State Medical University, Yekaterinburg, Russia

Chronic endometritis (CE) in women of the reproductive age is associated with infertility and recurrent pregnancy loss. The aim of this study was to evaluate the endometrial microbiota by means of real-time PCR in reproductive-age women depending on the morphological pattern of the endometrium. Using the Androflor real-time PCR kit, we analyzed endometrial aspirate collected from 23 patients with chronic endometritis, 30 patients with endometrial hyperplasia, and 19 healthy women. DNA of up to 9 groups of microorganisms was detected in all the analyzed samples in the amounts exceeding negative control. The total bacterial load (TBL) of the detected microorganisms was $10^{3}-10^{6,4}$ (median 10 $\left.0^{3,8}\right) \mathrm{GE} / \mathrm{ml}$. Lactobacillus spp. were detected the most often (86.1\% of all samples). Opportunistic microorganisms (OM) were identified in $36.1 \%$ of all samples, including $22.2 \%$ of samples with lactobacilli and $13.9 \%$ - without lactobacilli. The variant of microbiota composition with Lactobacillus-dominance (more than 90\%. in the TBL) was detected significantly less often in women with chronic endometritis compared to healthy women. Real-time PCR could be used for assessment of endometrial microbiota and allows us to determine its characteristics depending on the morphological pattern.

Keywords: endometrial microbiota, real-time PCR, chronic endometritis, Lactobacillus spp.

Acknowledgement: the authors thank Khayutin V, director of "Garmonia" Medical Center (Yekaterinburg), for letting them use its facilities for this research study. We thank to the Center for Precision Genome Editing and Genetic Technologies for Biomedicine (Moscow) for the genetic research methods.

Author contribution: Voroshilina ES organized the study, reviewed the literature, performed real-time PCR and statistical analysis, contributed to manuscript preparation; Zornikov DL reviewed the literature, conducted statistical analysis, contributed to manuscript preparation; Koposova OV reviewed the literature, performed molecular genetic assays; Islamidi DK analyzed medical histories, recruited patients, performed endometrial aspiration and pipelle biopsies, contributed to manuscript preparation; Ignatova KY conducted histological examinations; Abakumova El reviewed medical histories, recruited patients, performed endometrial aspiration and pipelle biopsies; Kurbatova NV reviewed medical histories, recruited patients, performed endometrial aspiration and pipelle biopsies; Plotko EE organized the study, reviewed the literature, contributed to manuscript preparation.

Compliance with ethical standards: the study was approved by the Ethics Committee of Ural State Medical University (Protocol № 7 dated September 20, 2019 ). Informed consent was obtained from all study participants.

Correspondence should be addressed: Ekaterina C. Voroshilina

Furmanova, 30, Yekaterinburg, 620142; voroshilina@gmail.com

Received: 03.02.2020 Accepted: 17.02.2020 Published online: 29.02.2020

DOI: $10.24075 /$ brsmu.2020.012

\section{ВОЗМОЖНОСТИ ОЦЕНКИ МИКРОБИОТЫ ПОЛОСТИ МАТКИ С ИСПОЛЬЗОВАНИЕМ ПЦР В РЕАЛЬНОМ ВРЕМЕНИ}

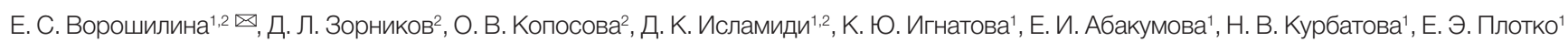

1 Медицинский центр «Гармония», Екатеринбург, Россия

2 Уральский государственный медицинский университет, Екатеринбург, Россия

Наличие хронического эндометрита (ХЭ) у женщин репродуктивного возраста ассоциируют с бесплодием и невынашиванием беременности. Целью работы было оценить состояние микробиоты полости матки методом полимеразной цепной реакции в режиме реального времени (ПЦР-РВ) у женщин репродуктивного возраста в зависимости от морфологической картины эндометрия. С помощью теста «Андрофлор" исследовали микробиоту аспирата эндометрия, полученного от 23 пациенток с ХЭ, 30 пациенток с гиперплазией эндометрия и 19 здоровых женщин. Во всех исследуемых образцах обнаружили ДНК от 1-9 групп микроорганизмов в количествах, превышающих показатели, полученные для отрицательных контрольных образцов. Общая бактериальная масса выявляемых микроорганизмов (ОБM) составила 103-106,4 (медиана 103,8) ГЭ/мл. В 86,1\% случаев выявили Lactobacillus spp. Условно-патогенные микроорганизмы идентифицировали в 36,1\% образцов, в том числе в 22,2\% - в сочетании с лактобациллами и в 13,9\% без лактобацилл. У пациенток с ХЭ достоверно реже в сравнении с группой здоровых женщин выявляли вариант микробиоты, характеризующийся наличием Lactobacillus spp. с удельным весом в ОБМ не менее 90\%. Таким образом, метод ПЦР-РВ может быть использован для оценки микробиоть полости матки и позволяет определить ее особенности при различной морфологической картине эндометрия.

Ключевые слова: микробиота эндометрия, ПЦР-PB, хронический эндометрит, Lactobacillus spp.

Благодарности: авторы благодарят В. Хаютина, директора медицинского центра «Гармония» (г. Екатеринбург), за возможность выполнения исследования на базе центра. Авторы признательны Центру высокоточного редактирования и генетических технологий для биомедицины (Москва) за помощь в методах исследования.

Вклад авторов: Е. С. Ворошилина - организация исследования, молекулярно-генетические исследования, анализ данных, статистический анализ, написание статьи; Д. Л. Зорников - анализ данных, статистический анализ, написание статьи; О. В. Копосова - анализ данных, молекулярногенетические исследования; Д. К. Исламиди - клинический анализ, отбор пациентов, взятие образцов, написание статьи; К. Ю. Игнатова патоморфологические исследования; Е. И. Абакумова - клинический анализ, отбор пациентов, взятие образцов; Н. В. Курбатова - клинический анализ, отбор пациентов, взятие образцов; Е. Э. Плотко - организация исследования, анализ данных, написание статьи.

Соблюдение этических стандартов: исследование одобрено этическим комитетом Уральского государственнго медицинского университета (протокол № 7 от 20 сентября 2019 г.). Все участницы исследования подписали добровольное информированное согласие на проведение исследования.

$\triangle$ Для корреспонденции: Екатерина Сергеевна Ворошилина ул. Фурманова, д. 30, г. Екатеринбург, 620142; voroshilina@gmail.com

Статья получена: 03.02.2020 Статья принята к печати: 17.02.2020 Опубликована онлайн: 29.02.2020

DOI: $10.24075 /$ vrgmu.2020.012 
For a long time, uterine cavity was thought to be sterile [1]. Recently, the implementation of molecular-based assays has made it possible to identify difficult to culture or unculturable microorganisms collected from the endometrial surface of reproductive-age women [2-7]. There is no consensus on the contribution of opportunistic microorganisms $(\mathrm{OM})$ to the development of endometrial inflammation [8, 9], and this raises doubts about the necessity of antimicrobial therapy in patients with chronic endometritis (CE). Importantly, CE is diagnosed in about $10 \%$ of women of reproductive age [10] and is associated with infertility and recurrent pregnancy loss [1, 8, 11-14].

For weak positive results of molecular assays, interpretation is always difficult due to the possibility of contamination of the analyzed sample. On the one hand, vaginal or cervical microbiota could be the source of such contamination because the transcervical method for endometrial sampling is common in clinical practice $[5,6]$. On the other hand, small concentrations of bacterial DNA could be present in DNA extraction kits (this is known as kitome) due to a number of reasons, and it is almost impossible to fully exclude the presence of contaminating DNA [15]. The latter does not present a problem when analyzing biotopes with high bacterial concentrations, such as feces or vaginal discharge, because in this case the concentrations of the analyzed DNA by far exceed those of the kitome. However, even minor amounts of such contaminants can endanger endometrial testing: in the endometrium, microbial concentrations rarely exceed $10^{4}$ cells per sample [16].

Currently, most endometrial microbiota testing relies on the use of next-generation sequencing (NGS) [3-6], which is an expensive and labor-intensive approach more suitable for scientific research rather than routine analysis and not universally available in practical healthcare. By contrast quantitative real-time polymerase chain reaction (real-time PCR) is a molecular technique most suitable for routine usage: robust, simple, affordable and easily standardized. However, there have been only few reports on the use of real-time PCR for endometrial microbiota analysis [7, 17].

The aim of this study is to evaluate a potential correlation of the state of endometrial microbiota and the morphological pattern of the endometrium in women of reproductive age by means of real-time PCR.

\section{METHODS}

\section{Participants}

Seventy-two reproductive-age women (age range 21-45 years, mean age $33 \pm 5.2$ years) who sought preconception care or medical advice about their reproductive health at the "Garmonia" Medical Center (Yekaterinburg) between September and December 2019 were recruited for the study.

The following inclusion criteria were applied: age of 18-45 years; no current pregnancy; a regular menstrual cycle; bad obstetric and gynecological history including infertility, induced or spontaneous abortion, missed abortion, chronic endometritis.

Exclusion criteria: intake of hormonal contraceptives or an intrauterine device at the time of examination or within 6 months before it; cancer; HIV; pelvic or lower genital tract inflammation at the time of examination; antibacterial treatment within 4 weeks before the study.

\section{Endometrial sampling}

Endometrial aspirates were collected on day 7-10 of the menstrual cycle using Endobrush Standard for Endometrial
Cytology (Laboratoire C.C.D.; France). Endobrush is protected from endocervical contamination by a sheath. It opens only after being introduced into the endometrial cavity and retracts into the sheath before withdrawal. For sampling, the cervix was brought into full view using a speculum. The cervix was swabbed with $0.05 \%$ chlorhexidine solution applied on a cotton ball, and the brush was inserted into the endometrial cavity so that it did not come in contact with the vaginal wall. After the brush was withdrawn from the endometrial cavity, the sheath surface was cleaned with a sterile swab soaked in 95\% ethanol in order to remove cervical discharge and prevent contamination of the specimen with cervical microbiota. Then the brush was released from the sheath and the specimen was immersed in PreservCyt Solution (Hologic, Inc.; USA) intended for the preservation of cell samples for in vitro diagnostic tests.

After endometrial aspiration, Pipelle biopsy was performed on all the participants in order to collect endometrial samples for a histopathological examination. Biopsy samples were placed into test tubes containing 10\% buffered formalin.

\section{DNA extraction}

DNA extraction was done using PREP-NA-PLUS kit (DNATechnology, Russia). Before DNA extraction, endometrial specimens were deproteinized. Briefly, test tubes containing endometrial aspirates were centrifuged in a MiniSpin centrifuge (Eppendorf; Germany) at 13,000 rpm for 10 min; the supernatant was removed, and the pellet was resuspended in $100 \mu$ of the lysing solution from the PREP-NA-PLUS kit. The homogenized sample $(50 \mu \mathrm{l})$ was transferred into a clean tube containing a mixture of $25 \mu \mathrm{l}$ of the lysing solution (from the PREP-NA-PLUS kit), $5 \mu$ of proteinase K (20 mg/ml) (WWR Life Science; USA) and $120 \mu$ of sterile normal $0.9 \%$ saline. After the components were mixed, the samples were incubated at $60^{\circ} \mathrm{C}$ for $30 \mathrm{~min}$ and then at $95^{\circ} \mathrm{C}$ for $10 \mathrm{~min}$. Upon incubation, the tubes were centrifuged at $13,000 \mathrm{rpm}$ for $60 \mathrm{~s}$. The supernatant (100 $\mu \mathrm{l})$ was then used for DNA extraction following the manufacturer's protocol.

\section{Evaluation of endometrial microbiota}

Detection of DNA of sexually transmitted obligate pathogens and of opportunistic microorganisms (OM) in the endometrial samples by means of real-time PCR was performed using the Androflor real-time PCR kit and DTPrime 4M1 real-time PCR instrument (DNA-Technology, Russia). The kit allows detection of a wide range of bacteria, which could play a role in endometrial inflammation. Androflor allows quantification of 24 groups of bacteria, including Lactobacillus spp., Staphylococcus spp., Streptococcus spp., Corynebacterium spp., Gardnerella vaginalis (G. vaginalis), Megasphaera spp., Veillonella spp., Dialister spp., Sneathia spp., Leptotrichia spp., Fusobacterium spp., Ureaplasma urealyticum (U. urealyticum), Ureaplasma parvum (U. parvum), Mycoplasma hominis (M. hominis), Atopobium cluster, Bacteroides spp., Porphyromonas spp., Prevotella spp., Anaerococcus spp., Peptostreptococcus spp., Parvimonas spp., Eubacterium spp., Haemophilus spp., Pseudomonas aeruginosa, Ralstonia spp., Burkholderia spp., Enterobacteriaceae spp./Enterococcus spp., Trichomonas vaginalis (T. vaginalis), Neisseria gonorrhoeae (N. gonorrhoeae), Chlamydia trachomatis (C. trachomatis), Mycoplasma genitalium (M. genitalium), and Candida spp.

The quantity of each bacterium/group of bacteria was automatically estimated from threshold cycle values, and the proportion of the microorganism in relation to the total bacterial 
load (TBL) was calculated. Sterile deionized water was used as a negative control (NC). For some groups of bacteria, NC produced positive signals at the cycle of quantification $(\mathrm{Cq})$ with value more than 35 (which corresponded to the bacterial DNA concentration of $<10^{3}$ genome equivalents per sample, GE/ sample). With that in mind, we assumed the DNA concentration of at least $10^{3} \mathrm{GE} /$ sample to be significant (Cq values less than 35). Lower values were interpreted as negative, considering the high sensitivity of the method and the inability to differentiate between potential DNA-contaminations and very weak positive signals in the samples.

$U$. urealyticum, $U$. parvum and $M$. hominis were an exception, as no positive signal was recorded in the NC. For these groups of microorganisms, a detectable signal during any amplification cycle was interpreted as positive.

\section{Histopathological examination}

Pipelle biopsy samples were subjected to a histopathological examination. The specimens were fixed in 10\% neutral buffered formalin and processed following the standard protocol. Paraffin sections of standard thickness $(5.0 \mu \mathrm{m})$ were stained with hematoxylin-eosin. Microscopy was carried out using a light binocular microscope Eclipse E200 (Nikon; Japan) (10x, 40x objective lens, 10x eyepiece lens).

\section{Statistical analysis}

The mean age of the patients was expressed as an average and a standard deviation. Average TBL and microbial concentrations were expressed as medians. Dispersion within the groups was described using $5^{\text {th }}$ and $95^{\text {th }}$ percentiles. These parameters were calculated in Microsoft Office Excel 2007 (Microsoft Corp.; USA).

The significance of differences between mean TBL and microbial concentrations was measured using the KruskalWallis test (for the comparison of 3 groups) and the Mann-
Whitney $U$ test (for the comparison of 2 groups). The data were processed in IBM SPSS Statistics 20 (IBM Corp.; USA). To compare frequencies between the groups, two-tailed Fisher's exact test was applied (WinPepi; JH Abramson; Israel). In all cases the differences were considered significant at $p<0.05$.

\section{RESULTS}

\section{Histopathological examination results}

Depending on the morphological appearance of the endometrium, the participants were divided into 3 groups [18].

Group 1 (chronic endometritis, CE) included 23 patients with $\mathrm{CE}$. The diagnosis was based on the signs of productive inflammation, formation of lymphoid follicles, endometrial stromal fibrosis, and sclerotic changes to the walls of spinal arteries.

Group 2 (endometrial hyperplasia, EHP) consisted of 30 patients with simple endometrial hyperplasia without atypia. The diagnosis was based on histology findings showing signs of cell proliferation in endometrial crypts and cytogenous stroma, spiral arteries with/without cell and nuclear polymorphism.

Group 3 (healthy women) included 19 patients without any structural changes in the endometrium; its morphology matched the day of the menstrual cycle.

\section{Molecular screening results}

Bacterial DNA was detected in all of 72 endometrial samples: TBL ranged from $10^{3}$ to $10^{6,4}$ (median: $10^{3,8}$ ) GE/sample. No significant differences in TBL were detected between the group of patients with endometrial pathology and healthy women. Endometrial TBL measured by real-time PCR varied 100-10,000-fold from vaginal TBL typically observed in reproductive-age women [19].

Lactobacillus spp. were detected the most often (in 86.1\% of cases; $n=62$ ). G.vaginalis were detected in 19

Table 1. Detection rate of bacterial groups determined by real-time PCR in morphologically different endometrial samples

\begin{tabular}{|l|c|c|c|c|}
\hline \multicolumn{1}{|c|}{ Groups of bacteria } & \multicolumn{3}{|c|}{ Detection rate in the studied patient groups $(n / \%)$} \\
\hline & $\begin{array}{c}\text { Group } 1-\mathrm{CE} \\
N=23\end{array}$ & $\begin{array}{c}\text { Group 2 - EHP } \\
N=30\end{array}$ & $\begin{array}{c}\text { Group 3 - healthy } \\
\text { women } N=19\end{array}$ & $\begin{array}{c}\text { Total } \\
N=72\end{array}$ \\
\hline Lactobacillus spp. & $19 / 82.6$ & $25 / 83.3$ & $18 / 94.7$ & $62 / 86.1$ \\
\hline Staphylococcus spp. & 0 & 0 & 0 & 0 \\
\hline Streptococcus spp. & $1 / 4.3$ & 0 & 0 & $1 / 1.4$ \\
\hline Corynebacterium spp. & 0 & $3 / 10.0$ & 0 & $3 / 4.2$ \\
\hline Gardnerella vaginalis & $7 / 30.4$ & $9 / 30.0$ & $3 / 15.8$ & $19 / 26.4$ \\
\hline Megasphaera spp. / Veillonella spp. / Dialister spp. & $1 / 4.3$ & $2 / 6.7$ & 0 & $3 / 4.2$ \\
\hline Sneathia spp. / Leptotrichia spp. / Fusobacterium spp. & $1 / 4.3$ & 0 & 0 & $1 / 1.4$ \\
\hline Atopobium cluster & $1 / 4.3$ & $3 / 10.0$ & 0 & $4 / 5.6$ \\
\hline Bacteroides spp. / Porphyromonas spp. / Prevotella spp. & $2 / 8.7$ & $3 / 10.0$ & $2 / 10.5$ & $7 / 9.7$ \\
\hline Anaerococcus spp. & 0 & $1 / 3.3$ & 0 & $1 / 1.4$ \\
\hline Peptostreptococcus spp. / Parvimonas spp. & $2 / 8.7$ & 0 & $2 / 10.5$ & $4 / 5.6$ \\
\hline Eubacterium spp. & $2 / 8.7$ & $3 / 10.0$ & $1 / 5.3$ & $6 / 8.3$ \\
\hline Haemophilus spp. & $1 / 4.3$ & 0 & 0 & $1 / 1.4$ \\
\hline Pseudomonas aeruginosa / Ralstonia spp. / Burkholderia spp. & 0 & $1 / 3.3$ & 0 & $1 / 1.4$ \\
\hline Enterobacteriaceae spp. / Enterococcus spp. & $4 / 17.4$ & $3 / 10.0$ & $1 / 5.6$ & $8 / 11.3$ \\
\hline Ureaplasma urealyticum & 0 & $1 / 3.3$ & 0 & $1 / 1.4$ \\
\hline Ureaplasma parvum & $4 / 17.4$ & $4 / 13.3$ & $1 / 5.3$ & $9 / 12.5$ \\
\hline Mycoplasma hominis & $3 / 13.0 \%$ & $2 / 6.7$ & 0 & $5 / 6.9$ \\
\hline
\end{tabular}


(26.8\%) samples, U.parvum, in $9(12,7 \%)$ samples, and Enterobacteriaceae spp. / Enterococcus spp., in 8 (11.3\%) samples. Other groups of microorganisms were detected in single samples (Table 1).

The detection rate of certain groups of bacteria varied in women with different histological pattern. Although the variance was insignificant, which might be explained by the small sample size, we noticed a few interesting trends. Only a few groups of $\mathrm{OM}$ included in the kit were detected in the samples with normal histological pattern. By contrast, OM detected in the samples collected from patients with CE and EHP represented the entire range of the target microorganisms, except for Staphylococcus spp.

Some OM were detected more frequently in women with CE and EHP. For example, DNA of G. vaginalis was found in $30 \%$ of patients with endometrial pathology, whereas only $16.7 \%$ of healthy women had this pathogen. U. parvum and M. hominis were detected in 17.4 and $13.0 \%$ of the samples that met the criteria for $\mathrm{CE}$, respectively, whereas only one woman from the group of healthy women had U. parvum.

No obligate sexually transmitted pathogens were detected in the endometrial tissue of our patients.

We detected from 1 up to 9 microbial groups in every sample (Fig. 1.) The endometrial microbiota of healthy women was represented by one group of bacteria in $78.9 \%$ of cases $(15$ of 19 samples), in their endometrium, whereas only $9(39.1 \%)$ of 23 patients with CE had one group of bacteria detected in their specimens $(p=0.013)$. Most often, the microbiota of patients with CE was represented by two microbial groups (11 or $47.8 \%$ of 23 samples). In patients with EHP, one group of bacteria was detected in 16 (53.3\%) of 30 samples; for the remaining 14 patients, the microbiota was represented by two or more bacterial groups. On the whole, the microbiota of patients whose histology was suggestive of EHP or CE tended to be more diverse in its composition than in healthy women.

Quantitative parameters for every group of bacteria are shown in Table 2. No statistical differences were observed between 3 groups of patients (CE, EHP, healthy women).

Given the large number of microbial groups identified by the kit, we decided to calculate the quantity of OM per sample for further analysis. Then, we calculated the proportion of lactobacilli and the proportion of OM relative to TBL per sample. Based on these calculations, 3 types of endometrial microbiota were distinguished:
Type 1) Lactobacilli-dominated type of microbiota. The proportion of Lactobacilli constituted no less than $90 \%$ of the TBL; the rest groups of bacteria were either undetected or found in very small quantities (less than $10 \%$ of the TBL).

Type 2) Mixed type microbiota. The proportion of Lactobacilli was no more than $90 \%$ (but at least 10\%) of the TBL, OM made up at least $10 \%$ of the TBL. Depending on the prevalent microorganisms, there can be subtypes of this microbiota type.

Type 3) Opportunistic microorganisms (OM)-dominated type microbiota (in the total absence of Lactobacillus spp.). Depending on the OM group detected, this type of microbiota can be also divided into a few subtypes.

Forty-six (63.9\%) of 72 samples met the criteria for type 1 microbiota; 16 (22.2\%),for type 2, and 10 (13.9\%), for type 3 . Thus, in the majority of the participants, the endometrial microbiota was represented by either lactobacilli or a combination of lactobacilli and the OM. In the next step, we analyzed the detection rate of the identified microbiota types in the studied groups of patients.

The endometrial microbiota of 16 (84.2\%) out of 19 healthy women fitted the criteria for type 1 (Lactobacilli-dominated) (Fig. 2). Two (10.5\%) of 19 samples met the criteria for type 2. Type 3 (OM-dominated) was identified in one (5.3\%) sample. Interestingly, OM were represented by $G$. vaginalis in all the 3 samples.

In patients with EHP, microbiota types 2 and 3 were detected more frequently than in healthy women, but the differences were statistically insignificant. Five $(16.7 \%)$ of 30 samples were classified as type 2; in all those samples, OM were represented by $G$. vaginalis. Type 3 was observed in 5 (16.7\%) samples; in 4 of them, OM were represented by $G$. vaginalis; in one case, by Enterobacteriaceae spp. / Enterococcus spp.

The greatest diversity was observed for the microbiota of women with CE. Type 1 (dominated by lactobacilli) was identified in $10(43.5 \%)$ of 23 women ( $p=0.012$, comparison with healthy women). Type 2 microbiota was observed in 9 (39.1\%) samples; in 5 of them, OM were represented by obligate anaerobes (G.vaginalis and Bacteroides spp. / Porphyromonas spp. / Prevotella spp.) and in other 4 samples, OM were represented by facultative gram-positive and gram-negative anaerobes. Type 3 microbiota was identified in $4(17.4 \%)$ of 23 samples. In this subset, OM were represented by $\mathrm{G}$. vaginalis in 2 cases and by Enterobacteriaceae spp. / Enterococcus spp. in one case; the association of Peptostreptococcus spp. I

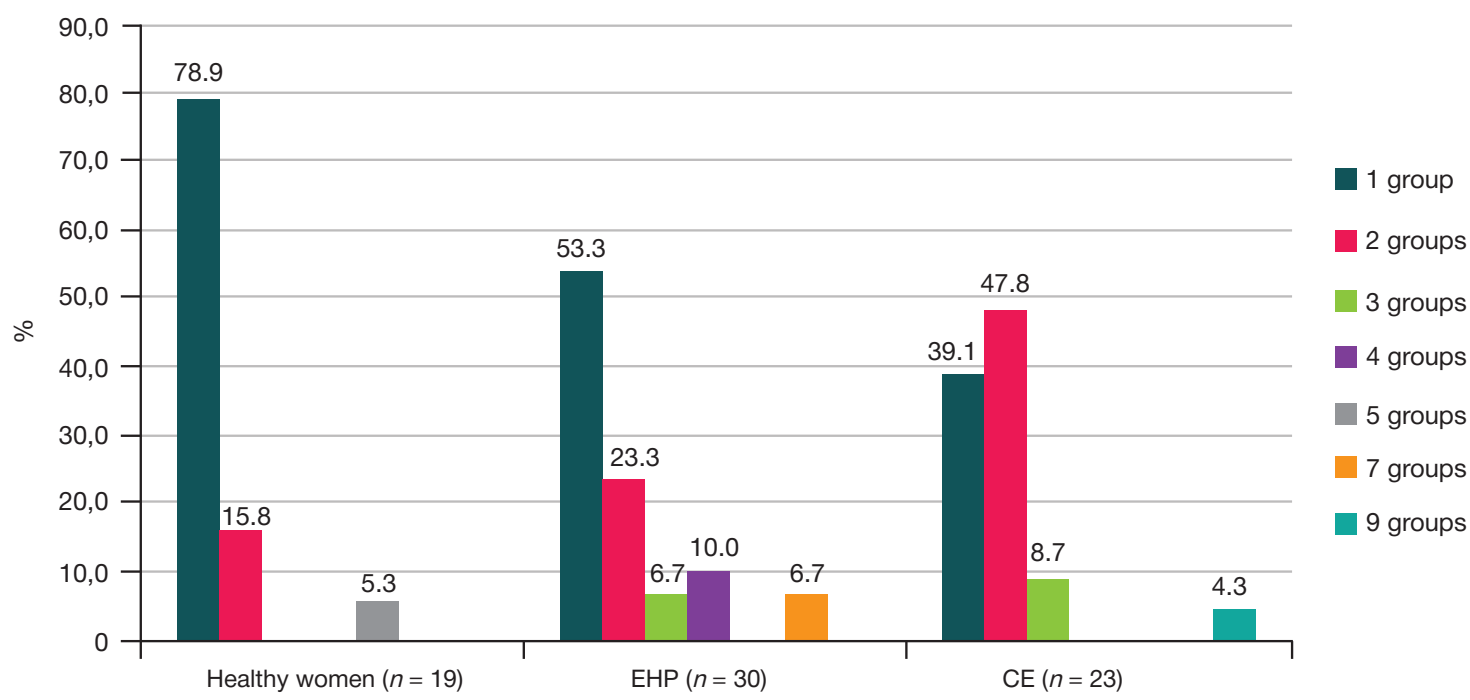

Fig. 1. The number of microbial groups detected per sample in patients with different morphological appearance of the endometrium $\left({ }^{*} p=0.013\right)$ 
Table 2. Qualitative and quantitative endometrial microbiota composition assessed by real-time PCR in the study participants $(N=72)$

\begin{tabular}{|c|c|c|c|c|}
\hline \multirow[b]{2}{*}{ Groups of bacteria } & \multicolumn{4}{|c|}{$\begin{array}{c}\text { Median } \\
\left(5^{\text {th }}-95^{\text {th }} \text { percentile }\right)\end{array}$} \\
\hline & $\begin{array}{c}\text { Group } 1 \\
\mathrm{CE}, N=23\end{array}$ & $\begin{array}{c}\text { Group } 2 \\
\mathrm{EHP}, N=30\end{array}$ & $\begin{array}{c}\text { Group } 3 \\
\text { Healthy women, } \\
\quad N=19\end{array}$ & $\begin{array}{l}\text { Total } \\
N=72\end{array}$ \\
\hline TBL & $\begin{array}{c}10^{3.8} \\
\left(10^{3.2}-10^{4.7}\right)\end{array}$ & $\begin{array}{c}10^{3.8} \\
\left(10^{3.3}-10^{5.1}\right)\end{array}$ & $\begin{array}{c}10^{3.9} \\
\left(10^{3.3}-10^{5.1}\right)\end{array}$ & $\begin{array}{c}10^{3.8} \\
\left(10^{3.3}-10^{5.1}\right)\end{array}$ \\
\hline Lactobacillus spp. & $\begin{array}{c}10^{3.8} \\
\left(0-10^{4.6}\right)\end{array}$ & $\begin{array}{c}10^{3.7} \\
\left(0-10^{5.1}\right)\end{array}$ & $\begin{array}{c}10^{3.8} \\
\left(10^{2.6}-10^{5.1}\right)\end{array}$ & $\begin{array}{c}10^{3.8} \\
\left(0-10^{4.9}\right)\end{array}$ \\
\hline Staphylococcus spp. & $\begin{array}{l}0 \\
0\end{array}$ & $\begin{array}{l}0 \\
0\end{array}$ & $\begin{array}{l}0 \\
0\end{array}$ & $\begin{array}{l}0 \\
0\end{array}$ \\
\hline Streptococcus spp. & $\begin{array}{l}0 \\
0\end{array}$ & $\begin{array}{l}0 \\
0\end{array}$ & $\begin{array}{l}0 \\
0\end{array}$ & $\begin{array}{l}0 \\
0\end{array}$ \\
\hline Corynebacterium spp. & $\begin{array}{l}0 \\
0\end{array}$ & $\begin{array}{c}0 \\
\left(0-10^{3.1}\right)\end{array}$ & $\begin{array}{l}0 \\
0\end{array}$ & $\begin{array}{l}0 \\
0\end{array}$ \\
\hline Gardnerella vaginalis & $\begin{array}{c}0 \\
\left(0-10^{3.8}\right)\end{array}$ & $\begin{array}{c}0 \\
\left(0-10^{3.7}\right)\end{array}$ & $\begin{array}{c}0 \\
\left(0-10^{3.2}\right)\end{array}$ & $\begin{array}{c}0 \\
\left(0-10^{3.8}\right)\end{array}$ \\
\hline Megasphaera spp. / Veillonella spp. / Dialister spp. & $\begin{array}{l}0 \\
0\end{array}$ & $\begin{array}{l}0 \\
0\end{array}$ & $\begin{array}{l}0 \\
0\end{array}$ & $\begin{array}{l}0 \\
0\end{array}$ \\
\hline Sneathia spp. / Leptotrichia spp. / Fusobacterium spp. & $\begin{array}{l}0 \\
0\end{array}$ & $\begin{array}{l}0 \\
0\end{array}$ & $\begin{array}{l}0 \\
0\end{array}$ & $\begin{array}{l}0 \\
0\end{array}$ \\
\hline Atopobium cluster & $\begin{array}{l}0 \\
0\end{array}$ & $\begin{array}{c}0 \\
\left(0-10^{3.2}\right)\end{array}$ & $\begin{array}{l}0 \\
0\end{array}$ & $\begin{array}{c}0 \\
\left(0-10^{1.5}\right)\end{array}$ \\
\hline Bacteroides spp. / Porphyromonas spp. / Prevotella spp. & $\begin{array}{l}0 \\
0\end{array}$ & $\begin{array}{c}0 \\
\left(0-10^{3.2}\right)\end{array}$ & $\begin{array}{c}0 \\
\left(0-10^{3.3}\right)\end{array}$ & $\begin{array}{c}0 \\
\left(0-10^{3.2}\right)\end{array}$ \\
\hline Anaerococcus spp. & $\begin{array}{l}0 \\
0\end{array}$ & $\begin{array}{l}0 \\
0\end{array}$ & $\begin{array}{l}0 \\
0\end{array}$ & $\begin{array}{l}0 \\
0\end{array}$ \\
\hline Peptostreptococcus spp. / Parvimonas spp. & $\begin{array}{c}0 \\
\left(0-10^{2.8}\right)\end{array}$ & $\begin{array}{l}0 \\
0\end{array}$ & $\begin{array}{c}0 \\
\left(0-10^{3.0}\right)\end{array}$ & $\begin{array}{c}0 \\
\left(0-10^{1.5}\right)\end{array}$ \\
\hline Eubacterium spp. & $\begin{array}{c}0 \\
\left(0-10^{2.7}\right)\end{array}$ & $\begin{array}{c}0 \\
\left(0-10^{3.0}\right)\end{array}$ & $\begin{array}{c}0 \\
\left(0-10^{0.5}\right)\end{array}$ & $\begin{array}{c}0 \\
\left(0-10^{3.0}\right)\end{array}$ \\
\hline Haemophilus spp. & $\begin{array}{l}0 \\
0\end{array}$ & $\begin{array}{l}0 \\
0\end{array}$ & $\begin{array}{l}0 \\
0\end{array}$ & $\begin{array}{l}0 \\
0\end{array}$ \\
\hline Pseudomonas aeruginosa / Ralstonia spp. / Burkholderia spp. & $\begin{array}{l}0 \\
0\end{array}$ & $\begin{array}{l}0 \\
0\end{array}$ & $\begin{array}{l}0 \\
0\end{array}$ & $\begin{array}{l}0 \\
0\end{array}$ \\
\hline Enterobacteriaceae spp. / Enterococcus spp. & $\begin{array}{c}0 \\
\left(0-10^{3.3}\right)\end{array}$ & $\begin{array}{c}0 \\
\left(0-10^{3.1}\right)\end{array}$ & $\begin{array}{c}0 \\
\left(0-10^{0.5}\right)\end{array}$ & $\begin{array}{c}0 \\
\left(0-10^{3.2}\right)\end{array}$ \\
\hline Ureaplasma urealyticum & $\begin{array}{l}0 \\
0\end{array}$ & $\begin{array}{l}0 \\
0\end{array}$ & $\begin{array}{l}0 \\
0\end{array}$ & $\begin{array}{l}0 \\
0\end{array}$ \\
\hline Ureaplasma parvum & $\begin{array}{c}0 \\
\left(0-10^{1.9}\right)\end{array}$ & $\begin{array}{c}0 \\
\left(0-10^{1.9}\right)\end{array}$ & $\begin{array}{c}0 \\
\left(0-10^{0.1}\right)\end{array}$ & $\begin{array}{c}0 \\
\left(0-10^{1.8}\right)\end{array}$ \\
\hline Mycoplasma hominis & $\begin{array}{c}0 \\
\left(0-10^{2.4}\right)\end{array}$ & $\begin{array}{c}0 \\
\left(0-10^{1 \cdot 1}\right)\end{array}$ & $\begin{array}{l}0 \\
0\end{array}$ & $\begin{array}{c}0 \\
\left(0-10^{2.2}\right)\end{array}$ \\
\hline
\end{tabular}

Parvimonas spp. and Enterobacteriaceae spp. / Enterococcus spp. was observed in one sample.

Thus, OM-dominated endometrial microbiota was more commonly observed in patients with CE.

\section{DISCUSSION}

In this study, endometrial microbiota was evaluated by realtime PCR, an inexpensive and technologically advanced technique. Our findings were consistent with the reports of other researchers who used costly techniques like NGS [2-6].

Bacterial DNA was detected in all endometrial samples in quantities ranging from $10^{3}$ to $10^{5} \mathrm{GE} /$ sample; DNA content differed between the samples 10-100-fold. Similar results are reported by other authors who collected samples transcervically $[2,5,6]$. This sampling approach carries a risk of contamination $[5,6]$. This could explain the presence of bacterial DNA in all samples analyzed in our study. For the sake of the experiment, the researchers analyzed endometrial samples collected from the middle section of the endometrial cavity after transabdominal hysterectomy in females of late reproductive age with uterine/endometrial pathology [20]. Bacterial DNA (in quantities exceeding NC counts) was detected in 60\% of the samples. However, such approach is unacceptable in clinical practice. The sampling technique and the device we used for transcervical collection of endometrial samples minimized the risk of contamination, but could not eliminate it completely.

Lactobacilli DNA was detected in the majority of the analyzed samples, which is also consistent with the literature [7]. Lactobacilli-dominated endometrial microbiota is considered to be a positive prognostic factor for successful embryo implantation via assisted reproductive technology and for good pregnancy outcome [2]. In our study, lactobacilli were detected in the majority of the samples, but their concentrations and proportion in relation to TBL varied.

Obligate and facultative anaerobes were detected in every third sample, both in the presence or absence of lactobacilli. 


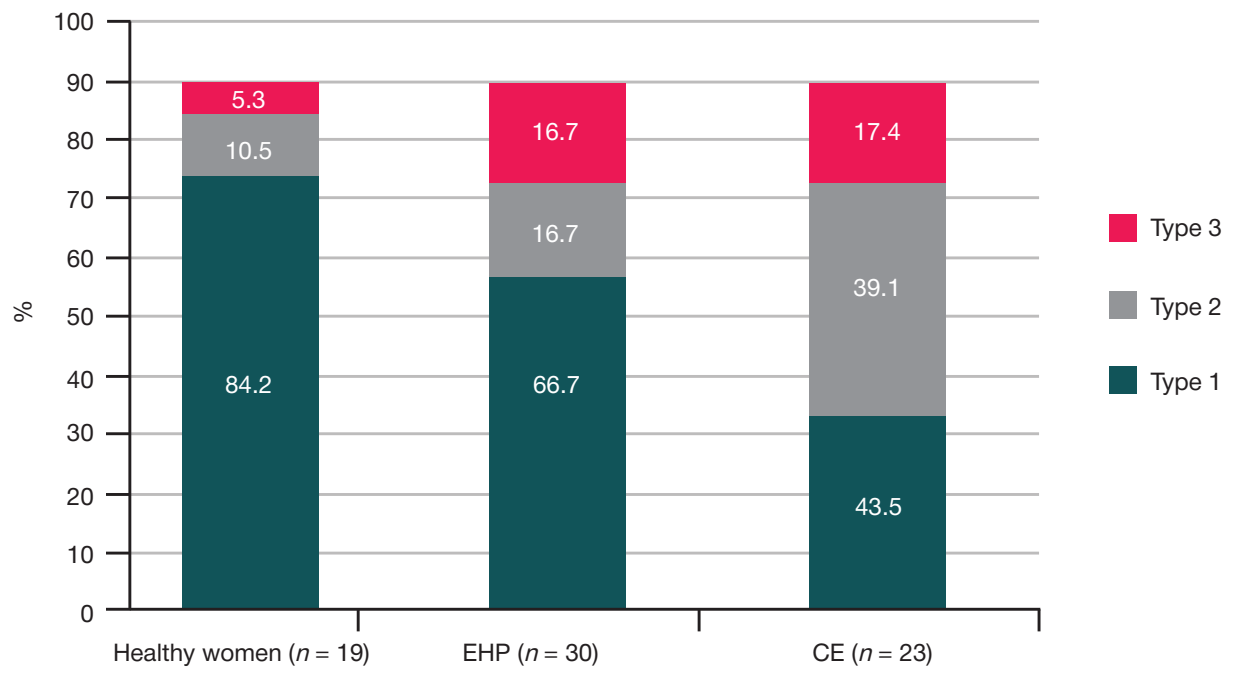

Fig. 2. Detection rate of different endometrial microbiota types in women with different morphological appearance of the endometrium $\left({ }^{*} p=0.011\right)$

OM were detected significantly less often in healthy women than in patients with CE.

Based on the proportion of lactobacilli and OM, we identified 3 types of endometrial microbiota; their detection rates varied in patients with CE or EHP and healthy women. In most cases, the endometrial microbiota of healthy women was represented by one group of microorganisms; as a rule, it was Lactobacillus spp. The presence of this microbiota type in women with CE does not seem to require antibacterial treatment and is consistent with contemporary views on the leading role of autoimmune mechanisms in the pathogenesis of CE. OM detected in the endometrial cavity of women with histology results suggestive of endometritis could be an additional marker indicating the significance of these bacteria for promoting inflammation. Further research is needed to explore a possible association between the presence of OM and EHP.

Our findings confirm that endometrial cavity is not a sterile environment. In some aspects, endometrial microbiota is similar to vaginal microbiota: in our study, lactobacilli were detected in the uterine cavity in $86.1 \%$ of all samples and were prevalent in the endometrial microbiota in $63.9 \%$ of all cases. At the same time, the quantity of bacteria present in the uterine cavity is much lower (100 to 10,000 -fold) than that in the vagina. Compositional similarities between the microbiotas of upper and lower female genital tracts and the role of lactobacilli found in the endometrial cavity are yet to be elucidated. Also, it is not clear whether the bacteria detected in the endometrium should be considered resident or transient microorganisms.

\section{CONCLUSIONS}

1. The use of real-time PCR allowed us to detect bacterial DNA in quantities exceeding those for the negative control in all endometrial aspirates. 2. In each sample of endometrial aspirate, 1-9 groups of microorganisms were detected. Lactobacillus spp. were the most common microorganism. They were detected in $86.1 \%$ of the specimens, of which $22.2 \%$ were characterized by a combination of Lactobacilli and $\mathrm{OM}$. The endometrial microbiota of $13.9 \%$ patients was represented by $\mathrm{OM}$ only (mostly, obligate anaerobes). 3. Comprehensive evaluation of the endometrial microbiota profile, based on the proportion of Lactobacillus spp. and OM in relation to the TBL allowed us to distinguish three microbiota types: Lactobacilli-dominated type, OM-dominated type, and mixed type. 4. In most women with histologically confirmed $\mathrm{CE}$, OM were detected in the endometrial microbiota, while in histologically normal endometrium Lactobacillus spp. were prevalent in the microbiota (the proportion in the TBL is not less than 90\%). 5. Currently, there is no unified approach to the diagnosis and treatment of chronic endometritis. Thus, the use of modern molecular-based techniques seems promising for evaluating endometrial microbiota and its role in the onset of the inflammatory process. A study of the microbiota of the endometrium by means of real-time PCR will allow us to verify the diagnosis and prescribe pathogenetically based therapy, which will improve the outcomes of subsequent pregnancies.

\section{References}

1. Cicinelli E, Matteo M, Tinelli R, Pinto V, Marinaccio M, Indraccolo U, et al. Chronic endometritis due to common bacteria is prevalent in women with recurrent miscarriage as confirmed by improved pregnancy outcome after antibiotic treatment. Reprod Sci. 2014; (21): 640-7.

2. Moreno I, Codoñer FM, Vilella F, Valbuena D, Martinez-Blanch JF, Jimenez-Almazán $\mathrm{J}$, et al. Evidence that the endometrial microbiota has an effect on implantation success or failure. Am J Obstet Gynecol. 2016 Dec; 215 (6): 684-703.

3. Moreno I, Franasiak JM. Endometrial microbiota-new player in town. Fertil Steril. 2017 Jul; 108 (1): 32-39.

4. Perez-Muñoz ME, Arrieta MC, Ramer-Tait AE, Walter J. A critical assessment of the "sterile womb" and "in utero colonization" hypotheses: implications for research on the pioneer infant microbiome. Microbiome. 2017 Apr 28; 5 (1): 48.

5. Baker JM, Chase DM, Herbst-Kralovetz MM. Uterine Microbiota: Residents, Tourists, or Invaders? Front Immunol. 2018 Mar 2; (9): 208.

6. Peric A, Weiss J, Vulliemoz N, Baud D, Stojanov M. Bacterial Colonization of the Female Upper Genital Tract. Int J Mol Sci. 2019 Jul 11; 20 (14) pii: E3405.

7. Tsypurdeeva ND, Shipitsyna EV, Savicheva AM, Gzgzyan AM, Kogan IYu. Composition of endometrial microbiota and chronic endometritis severity in patients with in vitro fertilization failures. Is there any connection? Journal of Obstetrics and Women's Diseases. 2018; 67 (2): 5-15. Russian

8. Cicinelli E, Resta L, Nicoletti R, Tartagni M, Marinaccio M, Bulletti C, 
et al. Detection of chronic endometritis at fluid hysteroscopy. J Minim Invasive Gynecol. 2005 Nov-Dec; 12 (6): 514-8.

9. Espinoza J, Erez O, Romero R, Preconceptional antibiotic treatment to prevent preterm birth in women with a previous preterm delivery. Am J Obstet Gynecol. 2006 Mar; 194 (3): 630-7.

10. Gombolevskaia NA, Marchenko LA. Modern diagnostic criteria of chronic endometritis (a review). Russian Journal of Human Reproduction. 2012; 18 (1): 42-6. Russian.

11. Kushnir VA, Solouki S, Sarig-Meth T, Vega MG, Albertini DF, Darmon SK et al. Systemic inflammation and autoimmunity in women with chronic endometritis. Am J Reprod Immunol. 2016; (75): $672-7$

12. Yang R, Du X, Wang Y, Song X, Yang Y, Qiao J. The hysteroscopy and histological diagnosis and treatment value of chronic endometritis in recurrent implantation failure patients. Arch Gynecol Obstet. 2014; (289): 1363-9.

13. Cicinelli E, Matteo M, Tinelli R, Lepera A, Alfonso R, Indraccolo U, et al. Prevalence of chronic endometritis in repeated unexplained implantation failure and the IVF success rate after antibiotic therapy. Hum Reprod. 2015; (30): 323-30.

14. Johnston-MacAnanny EB, Hartnett J, Engmann LL, Nulsen JC, Sanders MM, Benadiva CA. Chronic endometritis is a frequent finding in women with recurrent implantation failure after in vitro fertilization. Fertil Steril. 2010; (93): 437-41.

15. de Goffau MC, Lager S, Salter SJ, Wagner J1, Kronbichler A, Charnock-Jones DS, et al. Recognizing the reagent microbiome. Nat Microbiol. 2018 Aug; 3 (8): 851-3.

16. Salter SJ, Cox MJ, Turek EM, Calus ST, Cookson WO, Moffatt MF, et al. Reagent and laboratory contamination can critically impact sequence-based microbiome analyses. BMC Biol. 2014 Nov 12; (12): 87

17. Mitchell CM, Haick A, Nkwopara E, Garcia R, Rendi M, Agnew K, et al. Colonization of the upper genital tract by vaginal bacterial species in nonpregnant women. Am J Obstet Gynecol. 2015 May; 212 (5): 611.e1-9.

18. Palcev MA, Kakturskij LV, Zajrat'janc OV, editors. Pathological anatomy: national guide. M.: GJeOTAR-Media, 2014; 1264 p.

19. Voroshilina ES, Tumbinskaya LV, Donnikov AE, Plotko EA, Khayutin LV. Vaginal biocenosis in the context of view of quantitative polymerase chain reaction: what is its norm? Obstetrics and Gynecology. 2011; (1): 57-65. Russian.

20. Winters AD, Romero R, Gervasi MT, Gomez-Lopez N, Tran MR, Garcia-Flores V, et al. Does the endometrial cavity have a molecular microbial signature? Sci Rep. 2019 Jul 9; 9 (1): 9905.

\section{Литература}

1. Cicinelli E, Matteo M, Tinelli R, Pinto V, Marinaccio M, Indraccolo $U$ et al. Chronic endometritis due to common bacteria is prevalent in women with recurrent miscarriage as confirmed by improved pregnancy outcome after antibiotic treatment. Reprod Sci. 2014; (21): 640-7.

2. Moreno I, Codoñer FM, Vilella F, Valbuena D, Martinez-Blanch JF, Jimenez-Almazán J, et al. Evidence that the endometria microbiota has an effect on implantation success or failure. Am J Obstet Gynecol. 2016 Dec; 215 (6): 684-703.

3. Moreno I, Franasiak JM. Endometrial microbiota-new player in town. Fertil Steril. 2017 Jul; 108 (1): 32-39.

4. Perez-Muñoz ME, Arrieta MC, Ramer-Tait AE, Walter J. A critical assessment of the "sterile womb" and "in utero colonization" hypotheses: implications for research on the pioneer infant microbiome. Microbiome. 2017 Apr 28; 5 (1): 48.

5. Baker JM, Chase DM, Herbst-Kralovetz MM. Uterine Microbiota: Residents, Tourists, or Invaders? Front Immunol. 2018 Mar 2; (9): 208.

6. Peric A, Weiss J, Vulliemoz N, Baud D, Stojanov M. Bacterial Colonization of the Female Upper Genital Tract. Int J Mol Sci. 2019 Jul 11; 20 (14) pii: E3405.

7. Цыпурдеева Н. Д., Шипицына Е. В., Савичева А. М., Гзгзян А. М., Коган И. Ю. Состава микробиоты эндометрия и степень выраженности хронического эндометрита у пациенток с неэффективными протоколами экстракорпорального оплодотворения. Есть ли связь? Журнал акушерства и женских болезней. 2018; 67 (2): 5-15.

8. Cicinelli E, Resta L, Nicoletti R, Tartagni M, Marinaccio M, Bulletti C, et al. Detection of chronic endometritis at fluid hysteroscopy. J Minim Invasive Gynecol. 2005 Nov-Dec; 12 (6): 514-8.

9. Espinoza J, Erez O, Romero R, Preconceptional antibiotic treatment to prevent preterm birth in women with a previous preterm delivery. Am J Obstet Gynecol. 2006 Mar; 194 (3): 630-7.

10. Гомболевская Н. А., Марченко Л. А. Современные критерии диагностики хронического эндометрита (обзор литературы). Проблемы репродукции. 2012; 18 (1): 42-46.

11. Kushnir VA, Solouki S, Sarig-Meth T, Vega MG, Albertini DF,

Darmon SK et al. Systemic inflammation and autoimmunity in women with chronic endometritis. Am J Reprod Immunol. 2016 (75): 672-7

12. Yang $R$, Du X, Wang $Y$, Song $X$, Yang $Y$, Qiao J. The hysteroscopy and histological diagnosis and treatment value of chronic endometritis in recurrent implantation failure patients. Arch Gynecol Obstet. 2014; (289): 1363-9.

13. Cicinelli E, Matteo M, Tinelli R, Lepera A, Alfonso R, Indraccolo U, et al. Prevalence of chronic endometritis in repeated unexplained implantation failure and the IVF success rate after antibiotic therapy. Hum Reprod. 2015; (30): 323-30.

14. Johnston-MacAnanny EB, Hartnett J, Engmann LL, Nulsen JC, Sanders MM, Benadiva CA. Chronic endometritis is a frequent finding in women with recurrent implantation failure after in vitro fertilization. Fertil Steril. 2010; (93): 437-41.

15. de Goffau MC, Lager S, Salter SJ, Wagner J1, Kronbichler A, Charnock-Jones DS, et al. Recognizing the reagent microbiome. Nat Microbiol. 2018 Aug; 3 (8): 851-3

16. Salter SJ, Cox MJ, Turek EM, Calus ST, Cookson WO, Moffatt MF, et al. Reagent and laboratory contamination can critically impact sequence-based microbiome analyses. BMC Biol. 2014 Nov 12; (12): 87.

17. Mitchell CM, Haick A, Nkwopara E, Garcia R, Rendi M, Agnew K, et al. Colonization of the upper genital tract by vaginal bacterial species in nonpregnant women. Am J Obstet Gynecol. 2015 May; 212 (5): 611.e1-9.

18. Пальцев М. А., Кактурский Л. В., Зайратьянц О. В., редакторы. Патологическая анатомия: национальное руководство. М.: ГЭОТАР-Медиа, 2014; 1264 с.

19. Ворошилина Е. С., Тумбинская Л. В., Донников А. Е., Плотко Е. Э., Хаютин Л. В. Биоценоз влагалища с точки зрения количественной полимеразной цепной реакции: что есть норма? Акушерство и гинекология. 2011; (1): 57-65.

20. Winters AD, Romero R, Gervasi MT, Gomez-Lopez N, Tran MR, Garcia-Flores V, et al. Does the endometrial cavity have a molecular microbial signature? Sci Rep. 2019 Jul 9; 9 (1): 9905. 